\title{
Open Reduction and Internal Fixation of Displaced Fractures of Lateral Malleolus by Tension and Wiring and Plating in Bimalleolar Fractures in Adults
}

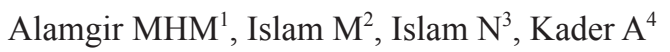

\begin{abstract}
Background: Lateral malleolus is the key structure for anatomic reduction of the displaced bi-malleolar fracture and that restored the integrity of stability of ankle. Therefore, accurate reduction and fixation is needed for proper functioning of the joint. Objectives: The purpose of the present study was to find out the better method of fixation for the unstable lateral malleolar fracture between tension band wiring and semitubular plating. Methodology: This was a prospective study carried out the National Institute of Traumatology and Orthopaedic Rehabilitation (NITOR) Dhaka during the period of July 2000 and June 2002. All the relevant data were collected for each individual patient on a predesigned data sheet and analyzed. A p value of $<0.05$ was taken as minimum level of significance. Result: Twenty patients were available till the final follow up. Tension band wiring was done for ten patients and semitubular plating for the rest ten patients. All fractures were united in 12 weeks in plating group and in tension band wiring group union occurred as early as 10 weeks. Radiological evaluation continued at 18th and 24th week showed no signs of osteoarthritis or any deformity. Conclusion: Displaced lateral malleolar fractures demands operative treatment and tension band wiring using $2 \mathrm{k}$-wires provide stronger fixation and fracture united early. [J Shaheed Suhrawardy Med Coll, 2013;5(2):81-83]
\end{abstract}

Keywords: Lateral malleolus, bimalleolar fractures, tension and wiring, open reduction, internal fixation

Received: April 2013; Revised: June 2013; Accepted: October 2013

\section{Introduction}

Fracture of ankle is the most common fractures involving joint ${ }^{1}$. Being a weight bearing joint maximum thrust passes through it. Ankle is a complex weight bearing joint and is subjected to many different type of injury. Testimony to this is the past and many of which are still in use ${ }^{1}$. It is the most common occurrence with exception of wrist fracture ${ }^{2}$.

Disability following ankle fracture may result in serious squeal like osteoarthritis. Slight variation from normal alignment of joint is incompatible with proper function. Therefore it is essential to obtain anatomic reduction and stability following such fracture ${ }^{3}$. It is very important in all the ankle fractures that a definitive diagnosis is made based on clinical evaluation of history, mechanism of injury, degree of immediate disability and obtaining proper radiograph to demonstrate leison ${ }^{4}$. Although closed reduction and immobilization has been tried for years yet the current opinion increasing favors for operative treatment for displaced fracture of lateral malleolus ${ }^{5}$. Lane and Denham ${ }^{6}$ were the first to emphasize the importance of perfect reduction. Burn also advocated for open reduction internal fixation ${ }^{7}$. There are three reasons for which it needs internal fixation such as difficulty in reduction, hard to hold reduced fracture while uniting, mobilization of joints and care of soft tissues not early $^{8}$. Lateral malleolus is the key structure to anatomic reduction and restoration of integrity of lateral malleolus established stability of ankle joint ${ }^{9}$. Lateral malleolus can be fixed by Rush nail, long screw and semitubular plate. Another method of fixation is tension band wiring.

The purpose of the present study was to find out the better method of fixation for the unstable lateral malleolar fracture between tension band wiring and semitubular plating.

1. Dr. MHM Alamgir, Assistant Professor, Department of Orthpaedic-Surgery, Shaheed Suhrawardy Medical College, Dhaka

2. Dr. Monowarul Islam, Associate Professor, Department of Orthpaedic-Surgery, Shaheed Suhrawardy Medical College, Dhaka

3. Dr. Md. Nazrul Islam, Resident Surgeon, Department of Orthpaedic-Surgery, Shaheed Suhrawardy Medical College \& Hospital, Dhaka

4. Dr. Abdul Kader, Junior Consultant, Aboynagar Health Complex, Jessor

Correspondence

Dr. MHM Alamgir, Assistant Professor, Department of Orthpaedic-Surgery, Shaheed Suhrawardy Medical. College, Sher-E-Bangla Nagar, Dhaka, Bangladesh; Email; d.malamgir@yahoo.com; Cell No.: +8801819144934

\section{Conflict of interest: None}

Financial Support: None

Contributions by authors: MHMA \& MI involved in protocol development, data collection, openative procedure as well as manuscript writings. MNI \& AK revised the manuscript 


\section{Methodology}

It was a clinical trial carried out at National Institute of Traumatology and Orthopaedic Rehabilitation, Dhaka from July 2000 and June 2002 for a period of 2(two) years. Initially there were 27 patients for study and 7 patients lost during follow up, therefore dropped from the study. All the adult patients both male and female with displaced lateral malleolar fracture alone or in combination with bimalleolar fracture in closed fracture and fresh fracture within 10 days were included in this study. Patients below 15 and above 40 years, trimalleolar fractures, open fractures, old fracture and poly trauma patients were excluded from this study. All patients were evaluated clinically as well as radiological basis. Injured leg was placed over the pillow to reduce the swelling and was advised to move toes. Informed consent was taken and discussed about operative procedure and accordingly all implants were kept ready. Operation was done using thigh tourniquet and under spinal anesthesia. A sort leg back slap applied at the end of operation. Proper antibiotics and analgesic were given. X-ray was taken immediately after operation in patients. All the relevant data were collected for each individual patient and categorized as excellent, good, and poor on the basis of Weber's criteria ${ }^{10}$.

\section{Results}

There were total 20 patients out of which 16 male and 4 were female with an age range of 30 to 40 years. Left sided involvement was $4(20 \%)$ cases and that of right side only $16(80 \%)$ cases. Average follow up duration was 24 weeks and hospital stay was 4 days with range of 3 to 14 days. Maximum patient belonged to age group 30 to 35 years $(70.0 \%)$.

Table 1: Different methods of fixation

\begin{tabular}{lcc}
\hline Method & Frequency & Percentage \\
\hline Semitubular plating & 10 & 50.0 \\
Tension band wiring & 10 & 50.0 \\
Total & $\mathbf{2 0}$ & $\mathbf{1 0 0 . 0}$ \\
\hline
\end{tabular}

Range of movement: Range of movement was measured at 6th, 12th ,18th and 24th week of follow up and it was observed that movement was better in semitubular group. Gait analysis shows normal in tension band wiring and $70 \%$ in semitubular plate group. Limping was reported in $20 \%$ in TBW and 30\% in semitubular group. Professional activities were better in TBW than that of semitubular group.

Table 2: Time of radiological union following fixation by 2 methods

\begin{tabular}{cccc}
\hline $\begin{array}{c}\text { Time of } \\
\text { Union }\end{array}$ & $\begin{array}{c}\text { Tension } \\
\text { Band Wiring }\end{array}$ & $\begin{array}{c}\text { Semitubular } \\
\text { Plating }\end{array}$ & Total \\
\hline $6 \mathrm{wks}$ & $6(60.0 \%)$ & $1(10.0 \%)$ & 7 \\
$8 \mathrm{wks}$ & $2(20.0 \%)$ & $1(10.0 \%)$ & 3 \\
$10 \mathrm{wks}$ & $2(20.0 \%)$ & $4(40.0 \%)$ & 6 \\
Total & $\mathbf{1 0}(\mathbf{1 0 0 . 0 \% )}$ & $\mathbf{1 0}(\mathbf{1 0 0 . 0 \% )}$ & $\mathbf{2 0}(\mathbf{1 0 0 . 0} \%)$ \\
\hline
\end{tabular}

*Chi-square test was performed; $\mathrm{p}=0.036$
Complications: Fragment displacement (medial melleolus) was seen in one case; persistent pain and tenderness in 2 cases in TBW and 3 cases semitubular plate. One case was found superficial infection in semitubular group. Two patients in semitubular group was developed vulgus deformity.

\section{Discussion}

As the ankle joint is a weight bearing joint, it transmits maximum thrush of the body; therefore it needs accurate reduction and internal fixation. Disability following bimalleolar fracture results in serious sequels like osteoarthritis and ankle instability. Any variation from normal alignment of joint is incompatible with proper function ${ }^{3}$.

In the past conservative procedure tried for years but current concept increasing favors for the operative treatment ${ }^{5}$. Displaced lateral malleolar fractures essentially demand open reduction and internal fixation to prevent any complication ${ }^{11}$. Lateral malleolus has a key role in displaced ankle fractures ${ }^{12}$. It does not lessen the necessity of anatomic reduction of medial malleolus ${ }^{13}$. It has been advocated three alternative options for fixing lateral malleolar fractures which are 2 or 3 inter fragmentary screws, double oblique lag screw from the tip and semitubular plating. Plating has pitfalls of wound healing and can not be in osteoporotic bone ${ }^{14}$. Semitubular plate fixation is biomechanically sound effective but it needs 2nd operation for removal ${ }^{15}$. Lateral malleolar fractures can be fixed by tension band wiring which is much effective and ensures biomechanically strong and more rigid fixation. It allows early union and mobilization. Moreover, it maintains the shape of ankle ${ }^{16}$.

In this study there were 20 patients upon whom two different methods of fixation carried out and follow up was taken for 24 weeks. Mean age (35 years) are consistent with other series ${ }^{17}$. Sex distribution is similar with Western series ${ }^{5,18-20}$. It is observed that in group with malleolar screw semitubular plate fixation, range of motion was better but no union up to 12 weeks. On the contrary where tension band wiring done union occurs early but range of motion is relatively restricted .Union occurs as early as 6th week in group where tension band done (both malleoli) is comparable with the result of Shahedhi ${ }^{17}$. Cases where combination of semitubular plate and tension band wiring were used, it has been showed early union in lateral malleolus and delayed in plate fixation group. Early weight bearing is satisfactory in group treated with tension band wiring. According to Carrage $^{20}$ a loss of more than $50 \%$ of total range of motion is considered as severe stiffness which interferes normal function of joint. In this study none of patients who were treated with tension band wiring was developed such complication. There are some other advantages of tension wiring and it is simple and easier to apply ${ }^{2}$. It can be applied in all sorts of fragments including small one. Chance of injuring superficial peroneal nerve is minimum and also cost effectiveness, almost several times cheaper than plate fixation ${ }^{4}$. 


\section{Conclusion}

It is concluded that displaced lateral malleolar fractures demand accurate reduction and internal fixation. With present trend of approach to fractures management where early movement and rehabilitation is the goal ,tension band wiring with $2 \mathrm{~K}$-wires provides much stiffer and stronger fixation which may be recommended for displaced lateral malleolar fractures.

\section{References}

1. Heim D, Heim U, Regazzoni P. Malleolar fractures with ankle joint instability--experience with the positioning screw. Unfallchirurgie. 1993;19(5):307-12

2. Colton CL, The treatment of Dupuytren's fracture dislocation. J Bone Joint Surg 1971;53B;63-70

3. de Souza LJ. Fracture and dislocation about ankle. In: Gustilo RB, Kyle RF, Templeman D, editors. Fracture and dislocation, New York ; Mosby Book Inc. 1993;pp997-1111

4. Denham RA. Internal fixation for unstable ankle fractures. J Bone Joint Surg 1964;56B;204-11

5. Burwell HN, Charnley AD. The treatment of displaced fractures at the ankle by rigid internal fixation and early joint movement .J Bone Joint Surg $1965 ; 47 \mathrm{~B} ; 634-60$

6. de Souza LJ, Gustilo RB , Meyer TJ. Result of operative treatment of displaced external rotation-abduction fracture of the ankle .J Bone Joint Surg $1985 ; 67 \mathrm{~A} ; 1066-73$

7. Danhers LE. The pathogenesis of and treatment of bimalleolar ankle fractures .Instructional course lecture, vol 39 American Academy of Orthopaedic Surgeons, 1990;84-94
8. Muller ME, Allgower M, Schneider R, Willengegger H. Basic aspect of internal fixation. 3rd edition1992; pp.1-3

9. Winkler B, Weber BG, Simpson LA. The Dorsal Antiglide Plate in the Treatment of Dank-Weber Type-B Fractures of the Distal Fibula. Clinical orthopaedics and related research. 1990;259:204-9

10. Wilson FC. Fractures and dislocation of ankle .In Rockwood CA, Green DP,FRACTURE 3RD edi., Philadelphia; JP Lippincott, 1984;pp.1363-98

11. Litchfied JC. Treatment of unstable fractures of ankle in elderly. Injury 1987; 18;128-32

12. Yabon IG, Heller FG, Shsuse L. The key role of lateral malleolus in displaced fractures of ankle J Bone Joint Surg1977;59A;169-73

13. Philips WA. Evaluation of ankle fractures; Non-operativ vs operative. Clin Orthop Related Res 1979;138;17-21

14. Wilsonjr FC, Skilbred LA. Long-term results in the treatment of displaced bimalleolar fractures. The Journal of Bone \& Joint Surgery 1966;48(6):1065-78

15. O'Leary C, Ward FJ. A unique closed abduction-external rotation ankle fracture. J Trauma 29:119,1989

16. Olerud S, Johansson H. The lateral malleolus. Ann Dig Foreign Orthop Lit 3rd qrt:29,1970

17. Ahmed M. Study and evaluation of results of open reduction and internal fixation of closed displaced malleolar fractures in adults [thesis] Dhaka University, Dhaka; 1992

18. Wilson FC. The pathogenesis and treatment of ankle fracture: classification, American Academy of Orthopaedic Surgeon, Instructional course lecture 39:79,1990

19. Edwards GS, DeLee JC. Ankle diastasis without fracture. Foot \& Ankle International. 1984;4(6):305-12.

20. Carrage EJ. Early complications in operative treatment of ankle fractures. J Bone Joint Surg1991:73B:79-82. 